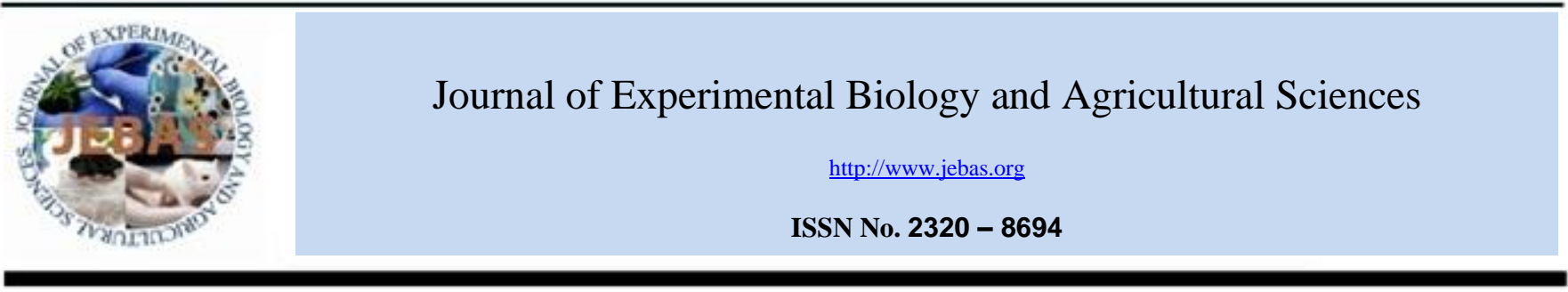

\title{
INFLUENCE OF PHYSICO-CHEMICAL PARAMETERS ON POPULATION STRUCTURE AND LENGTH-WEIGHT RELATIONSHIP OF Artemia franciscana
}

\author{
Balachandar Shanmugasundaram ${ }^{1}$, Rajaram Rajendran ${ }^{2, *}$ and Veeramani Thangasamy ${ }^{2}$
}

${ }^{1}$ Rajiv Gandhi Centre for Aquaculture, Artemia project, 2/340, Rajiv Gandhi Road, Tharuvaikulam P.O., Ottapidaram Tk, Tuticorin Dt., Tamil Nadu-628105.

${ }^{2}$ Department of Marine Science, Bharathidasan University, Tiruchirappalli - 620 024, Tamil Nadu, India.

Received - December 28, 2016; Revision- February 01, 2017; Accepted - February 26, 2017

Available Online - February 28, 2017

DOI: http://dx.doi.org/10.18006/2017.5(1).126.133

\section{KEYWORDS}

Biomass

Salt pan

Physicochemical parameters

Artemia franciscana

\begin{abstract}
The Artemia franciscana populations were found throughout the year in Tuticorin saltpan ecosystem. In order to provide better growth and understanding of brine shrimp A. franciscana, the different ecological and biological parameters were taken out during 4 different seasons from January to December 2014. This study determines the impact of algae on growth and physicochemical parameters on population structure and length-weight of Artemia in different seasons of man-made saltpan habitat and algae fed Artemia culture pond at Tuticorin. Maximum population density of brine shrimp was observed in the monsoon season nauplii $54.91 \%$ \& $52.77 \%$, juvenile $20.52 \%$ \& $20.03 \%$, pre-adult $15.31 \& 14.48 \%$, male $4.91 \& 7.53 \%$, female $4.33 \& 5.15 \%$ were observed in Station $1 \& 2$ respectively and decline was observed in summer season. The length was observed to the maximum of $8729.44(\mu \mathrm{m}) \& 9696.00$ $(\mu \mathrm{m})$, and the minimum of $7909.77(\mu \mathrm{m}) \& 8367.11(\mu \mathrm{m})$ in Station 1 \& Station 2 respectively; maximum weight ranged from $0.007 \mathrm{~g} \& 0.009 \mathrm{~g}$ in Station $1 \&$ Station 2 respectively. The sex- ratio showed that males pre-dominated than females during the entire season in both stations. Based on the present study the growth and abundance of Artemia population were high in station 2 because of the enrichment of the algae supplementation.
\end{abstract}

* Corresponding author

E-mail: drrajaram69@rediffmail.com (Rajaram Rajendran)

Peer review under responsibility of Journal of Experimental Biology and Agricultural Sciences.

Production and Hosting by Horizon Publisher India [HPI] (http://www.horizonpublisherindia.in/).

All rights reserved.
All the article published by Journal of Experimental Biology and Agricultural Sciences is licensed under a Creative Commons Attribution-NonCommercial 4.0 International License Based on a work at www.jebas.org.

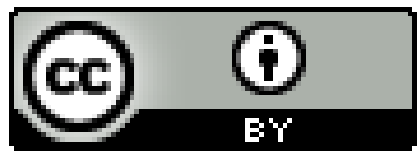




\section{Introduction}

Artemia is an excellent food source, which could provide quality feed to fish and crustaceans and help in the growth of aquaculture industry (Sorgeloos, 1980). The brine shrimp A. franciscana was mostly reported from the hyper saline environments and distributed all over the world (Van Stappen, 2002) and extensively used in aquaculture. In order to meet the increasing demand of Artemia cysts and producing high quality biomass, solar salt pond management techniques has been indiscriminately introduced worldwide into a large number of salterns and salt lakes (Persoone \& Sorgeloos, 1980; Geddes \& Williams, 1987; Tackaert \& Sorgeloos, 1991). The need of finfish and crustacean species has increasing now a days, it seem to have the potential of aquaculture market to world need, but live food availability is one of the major constraints for the culture development of these species. Studies on Artemia populations and morphometric characters are important to know about their adaptability, size and growth of the animal for pilot scale production. Various researchers those who have conducted the field studies have forgot to include the relationship between population and morphometric characters on Artemia culture (Lenz \& Browne, 1991; Browne, 1992; Browne, 1993)

Algae play an important role in Artemia growth and development (Mason, 1963) however, Artemia could not filter larger algae, especially filamentous algae (e.g. Ossilatoria) because they become a trap which can prevent movement of Artemia and it reduces their survivability (Sorgeloos et al., 1986; Dhont \& Lavens, 1996). It is a continuous filter feeder which selects suspended particles only on the basis of size
(Gelabert \& De la Cruz, 1990); although it's feeding behavior may be affected by several factors which influence its filtration, ingestion, or assimilation rates. In addition it varies with age because the feeding efficiency increases with the number of functional thoracopods (Lavens \& Sorgeloos, 1991).

Artemia populations can sustain in temperature oscillation and it can able to live even at 6 to $35^{\circ} \mathrm{C}$ with different ionic salt composition. Similarly, Artemia populations also have adaptation towards the water $\mathrm{pH}$ and these can tolerate $\mathrm{pH}$ from neutral to highly alkaline (Van Stappen, 2002).Therefore, the differences in physicochemical properties of water such as temperature, $\mathrm{pH}$, salinity and oxygen level play an important impacts on the fluctuation of Artemia populations by influencing their reproductive strategies through ovoviviparous versus cyst production (Camargo et al., 2004). The aim of present study was to evaluate the physicochemical properties, population and morphometric characters of A. franciscana in Tuticorin saltpan ecosystem and in the Artemia culture ponds.

\section{Materials and Methods}

\subsection{Site description}

Study was conducted at Tharuvaikulam (Latitude $8^{\circ} 44^{\prime}$ $40.07^{\prime}$ 'N ; Longitude $78^{\circ} 07^{\prime} 27.87^{\prime \prime} \mathrm{E}$ ) which is situated at 10 $\mathrm{km}$ north to Tuticorin city (Figure 1). Study area was divided into two locations viz. 1. Manmade saltern and 2 Artemia culture pond. Selected areas have higher salt production as compared to other stations and also have very high Artemia density.

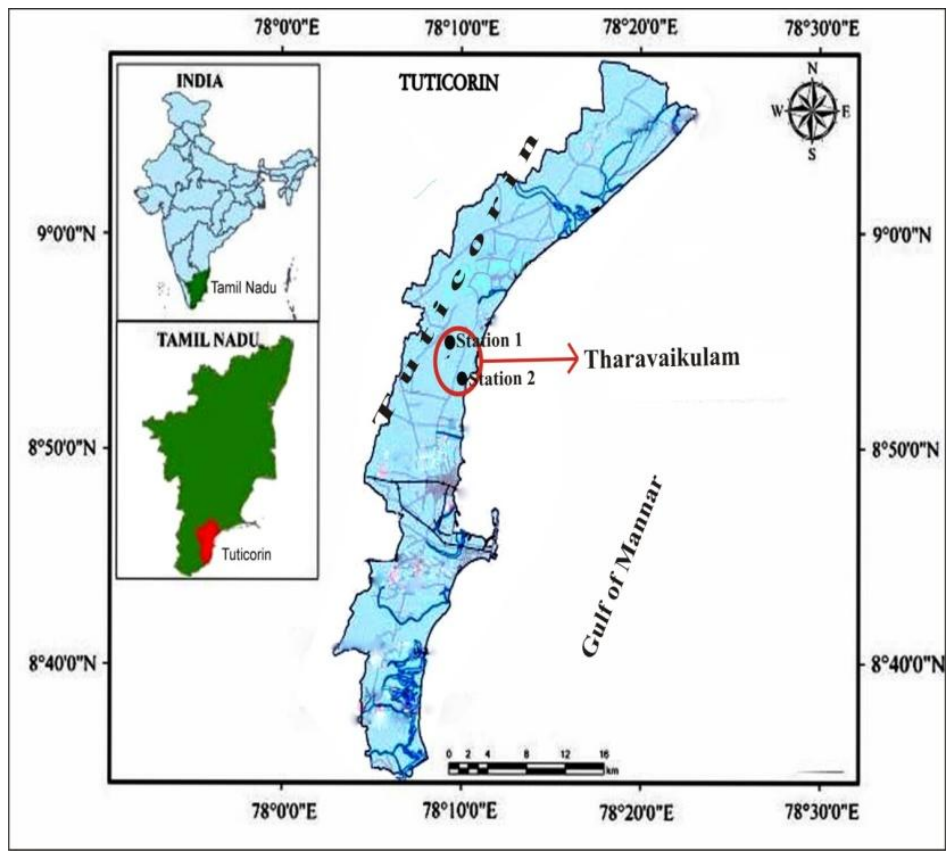

Figure 1 Geographical location of the study area. 
2.2 Sample collection and hydrobiological parameters

Water and Artemia samples were collected for the period of 1 year from January to December 2014. The physicochemical and biological parameters of the collected samples were analyzed. Among these, salinity, temperature and $\mathrm{pH}$ were observed by standard methodological instruments (Hand Refractometer - ATAGO, Digital Thermometer and $\mathrm{pH}$ meter - Handy lab1). Artemia samples were collected by $150 \mu \mathrm{m}$ mesh size of nylon net and preserved in 5\% formaldehyde for biometric analysis. The biological parameters like population density of A. franciscana were analyzed by using standard methods described by Amart (1979) and Vanhaecke \& Sorgeloos (1980).

\subsection{Population composition}

Abundance of Artemia population was determined in 1 liter of collected water from each station. Abundance was determined by directly counting Artemia specimens by using a magnifying glass. In most of the cases, entire one liter sample was used to calculate abundance while in some samples where as Artemia population is too high; samples were divided in subsamples and used for estimation of population density. At each census, Artemia individuals were lightly narcotized with chloroformsaturated water and then sorted into four demographic classes. To determine the population composition, the nauplii (larvae without thoracopods), juveniles (larvae with thoracopods but not sexually differentiated), pre-adults (specimens sexually differentiated and not having reached the reproduction stage) and adults were numbered. Adults Artemia length were measured individually in a ventral position from the tip of the head to the base of the furca.

\subsection{Length and weight}

Average length was measured for 30 adults of Artemia and mean values were used for comparison. In all specimens, the total length (between top of head to base of caudal furca) was measured using optical microscope equipped with a calibrated micrometer eye piece.

\section{Results}

\subsection{Physico-chemical parameters}

The physico-chemical parameters of the collected water samples were measured for each station, these samples were divided into 4 seasons including post-monsoon, summer, premonsoon and monsoon. Highest temperature for station 1 (Manmade saltern) was reported $38.16^{\circ} \mathrm{C}$ during the summer seasons while the lowest $33.5^{\circ} \mathrm{C}$ was recorded in monsoon season. Results of study revealed that temperature of water samples varied with the sampling location (Figure 2). Average water temperature for this station was around $35.5^{\circ} \mathrm{C}$ for the entire year. Similar trends was reported for the water temperature of station 2 (Artemia culture pond) and was also showing maximum temperature $\left(37.6^{\circ} \mathrm{C}\right)$ during summer and minimum $\left(33.3^{\circ} \mathrm{C}\right)$ in monsoon season. The average water temperature for this station was also around $35.4^{\circ} \mathrm{C}$ for the entire year.

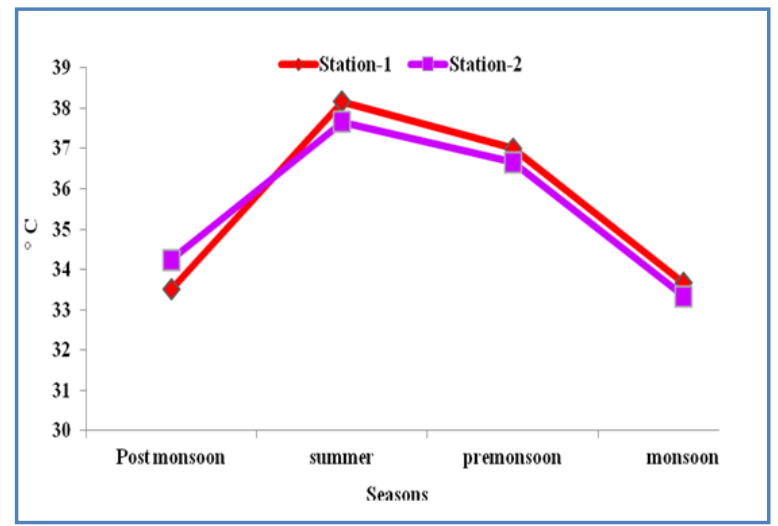

Figure 2 Variations of water temperature recorded in station 1 and 2 .

Further, in case of salinity, highest salinity $117.33,104.00 \mathrm{ppt}$ was reported during the summer while the lowest salinity $55.00,57.33$ ppt was reported in monsoon season for the station 1 and 2 respectively. Salinity of the two study areas varied with little difference which depend on the various season (post monsoon, summer, Pre monsoon and monsoon) (Figure 4). Like other parameters, in case of $\mathrm{pH}$, maximum $\mathrm{pH}$ $(8.30,8.40)$ was reported during summer while the minimum $\mathrm{pH}(7.73,7.93)$ was reported in the monsoon season from the station 1 and 2 respectively (Figure 3 ).

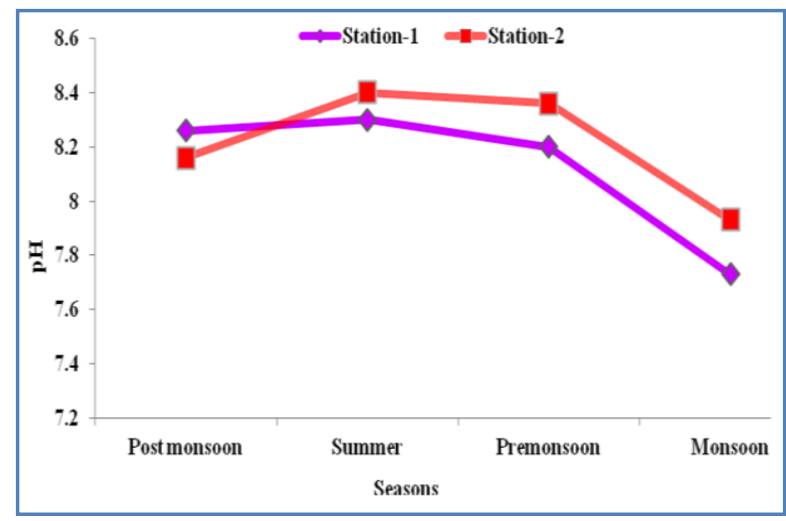

Figure 3 Variations of $\mathrm{pH}$ recorded in station 1 and 2.

\subsection{Population variation}

Wide variations was reported in the population abundance of Artemia at 2 stations (Figures $5 \& 6$ ). Total mean value of Artemia population significantly varied between seasons to seasons. However, some decline was observed in summer season. The number of individuals collected at monthly interval has varied and the lowest population was observed during summer season in both stations. 


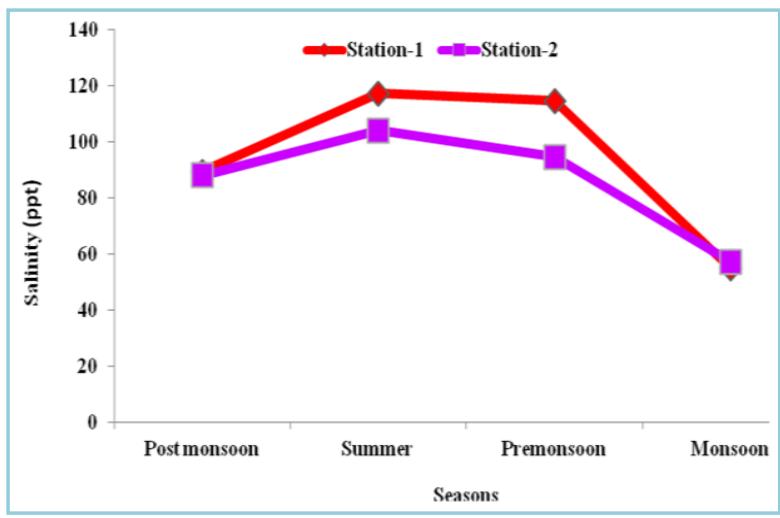

Figure 4 Variations of salinity recorded in station 1 and 2.

In both the stations, total population of nauplii consisted of $51.28 \%$ and $49.51 \%$, juvenile composition was $22.43 \%$ and $24.5 \%$ and the Artemia pre-adult stage was $14.74 \%$, \& $13.72 \%$ respectively. While determining the sex ratio of the species male comprised $5.76 \%, 6.86 \%$ while this percentage was reported $5.76 \%, 5.39 \%$ per liter of water in case of female for station 1 and 2 respectively. Maximum population density was reported in the monsoon season and this percentage was $54.91 \%$ \& $52.77 \%$ for nauplii, $20.52 \% \& 20.03 \%$ for juvenile, $15.31 \% \& 14.48 \%$ for pre-adult, $4.91 \% \& 7.53 \%$ for male and $4.33 \%$ \& 5.15 for female in one liter of water for the station 1 and 2 respectively.

The sex- ratio was predominated with male Artemia population and always slightly higher than female population. During the experimental observation nauplii composition was high in all the four seasons for both the studied stations. For the population composition, nauplii made up a very high fraction of the samples in all the four seasons (more than 50\%).
Furthermore, the Artemia concentration was predominated in station 2 as compared to the station 1 for all the seasons, it may be due to the availability of the micro algae. The algae density was maintained in the separate algal ponds and supplied to the Artemia culture ponds in station 2 . The highest algal density was appeared in the post-monsoon season. Overall average algal density was observed $173425.66 / \mathrm{ml}$ in post monsoon, $150841.00 / \mathrm{ml}$ in summer, $168388.66 / \mathrm{ml}$ in pre-monsoon and $162500 \mathrm{cells} / \mathrm{ml}$ in monsoon season.

The strong relationship found between distributed algal species with the water salinity. Therefore the abundant planktonic diversity was observed even at different salinity regimen, under seasonal influence. Compared to all other planktonic species Dunaliella salina was more predominant in hypersaline ponds while other planktons including Oscillatoria, Pleurosigma, Navicula and Nitzschia were common in all. Dunalliela salina was the only species consistently recorded in high number from all stations.

\subsection{Length \& weight relationship of Artemia}

The length, dry and wet weight measurements of Artemia population in two stations are presented (Figures 7, $8 \&$ 9). Results of study revealed that both populations are significantly different in growth performance. Maximum Artemia length was observed during the monsoon season $(8729.44 \mu \mathrm{m} \& 9696.00 \mu \mathrm{m})$ while it was reported minimum in summer season $(7909.77 \mu \mathrm{m} \& 8367.11 \mu \mathrm{m})$ for station $1 \& 2$ respectively. Further, the maximum weight was recorded during monsoon $0.007 \mathrm{~g} \& 0.009 \mathrm{~g}$ while the minimum weight was observed during summer season $0.005 \mathrm{~g} \& 0.007 \mathrm{~g}$ for station 1 and 2 respectively but it was not significantly different.

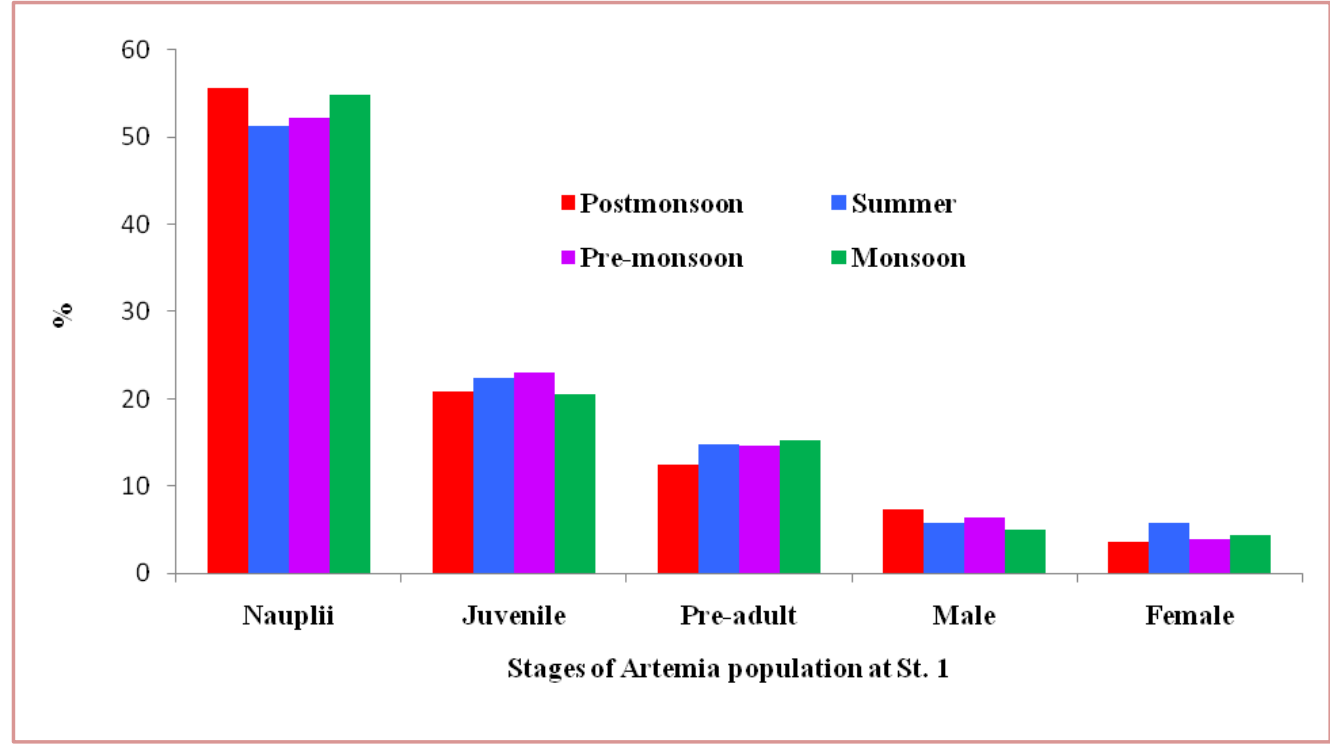

Figure 5 Variations in different stages of Artemia during four different seasons at station 1. 


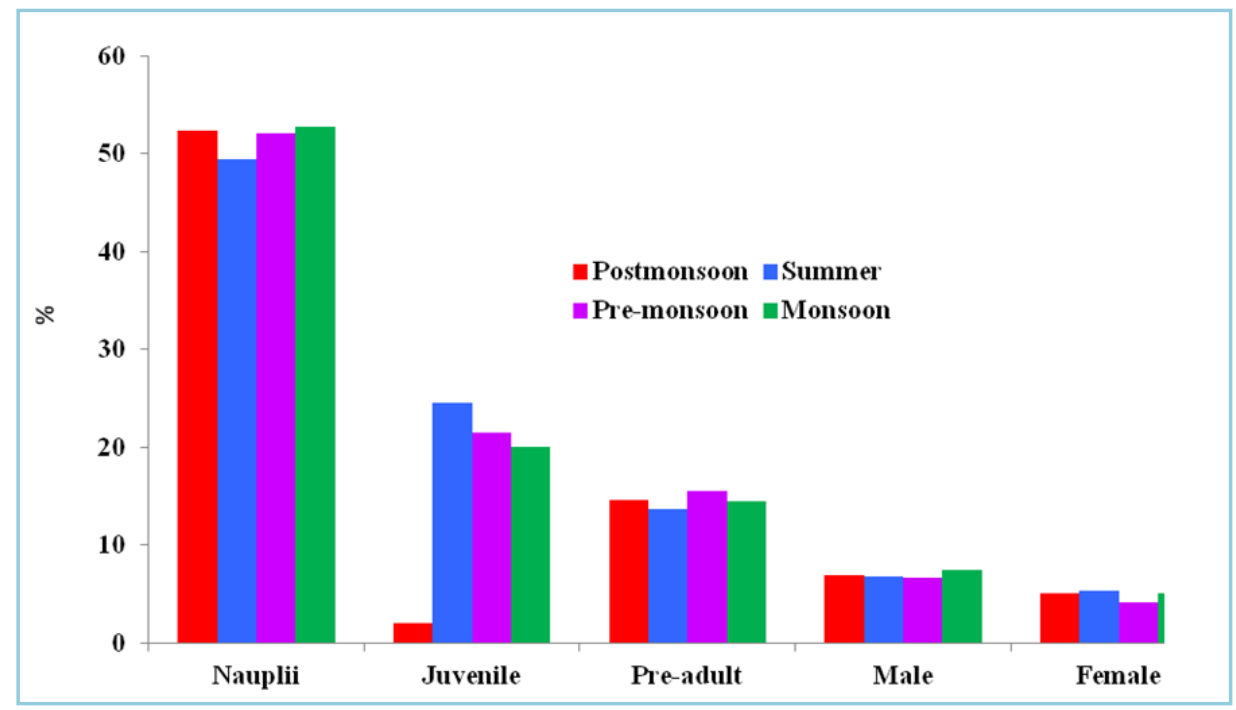

Figure 6 Variations in different stages of Artemia during four different seasons at station 2.

\section{Discussions}

The physicochemical parameters were observed in both stations and the peak value of temperature was reported $38.16^{\circ} \mathrm{C}$, Salinity $117.33 \mathrm{ppt}$ and $\mathrm{pH} 8.40$ noticed, results of present study are in conformity with the findings of Persoone \& Sorgeloos, (1980). Similarly, Kulasekarapandian \& Ravichandran (2003) has described that the physicochemical properties and population analysis of Chennai water and the similar results were noticed in the present study with slight variations in salinity. In the present study, Artemia population density was observed maximum during the monsoon season. The density of Nauplii was 54.91 to $52.77 \%$ and the similar observations were made by Razia sultana et al. (2011). The physicochemical properties, population analysis and size variation observed in the present study was similar to Shaikha Al Dhaheri \& Anitha Saji (2013). Radhika et al. (2011) studied the physicochemical and population analysis in Tuticorin environment and noticed the similar kind of results. In the present study, the reported physicochemical parameters are within the normal range but Al Dhaheri (2004) reported Artemia can tolerate and survive up to 237 ppt of salinity.

The physicochemical and various hydrological characters of water play an important role in the determinant of development of biological community of saltpans (Davis, 2000). Van Stappen, (2002) reported that Artemia can survive in wide range of $\mathrm{pH}$ which varies from neutral to highly alkaline. Interestingly, the physicochemical parameters impacts on Artemia populations by influencing their reproductive strategies through ovoviviparism versus cyst production (Camargo et al., 2004) and morphological characters of adult specimens (Gilchrist, 1960; Hontoria \& Amat, 1992; Litvinenko et al., 2007; Asem \& Rastegar-Pouyani, 2008; Ben Naceur et al., 2011a). During the present study, high evaporation of water, high salinity, low oxygen and neutral $\mathrm{pH}$ are the characteristic features of the salt pans which were also observed (Gunde Cimerman et al., 2000).

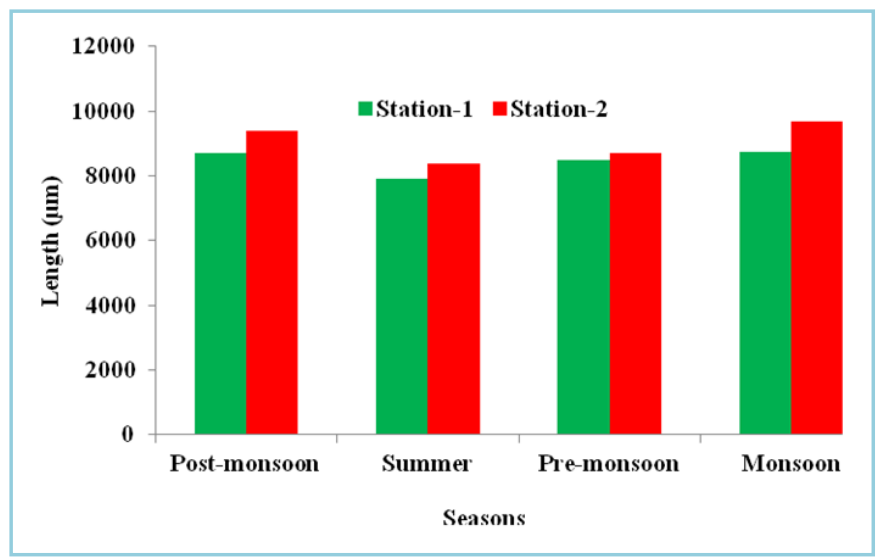

Figure 7 Length of Artemia in Station 1 and 2 during four different seasons. 


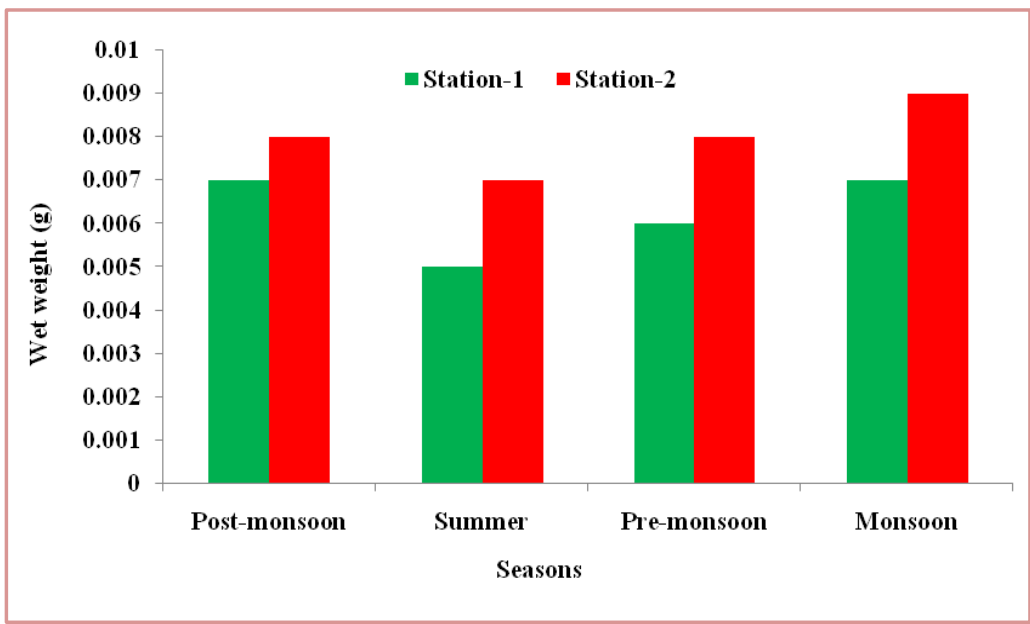

Figure 8 Wet weight of Artemia in Station 1 and 2 during four different seasons.

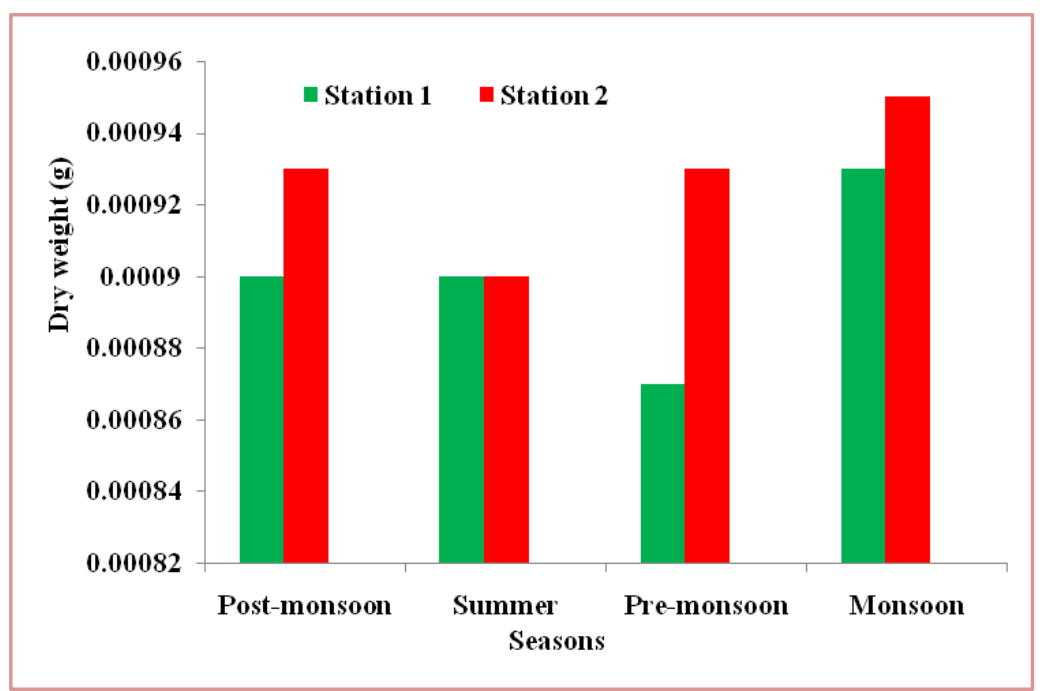

Figure 9 Dry weight of Artemia in Station 1 and 2 during four different seasons.

The abundance of micro plankton was observed and dominated by diatoms and dinoflagellates which accounted about $90 \%$ of the total abundance in the saltpan. However, the diversity and species richness remained poor in the salt pans (Rehman, 2006). The above study demonstrated that salt pans represent discrete ecosystem among the saline zones which has a unique life restricted to these system only. Despite the heavy constraints, temperature plays a regulatory factor in the development of plankton community of these systems (Ayadi et al., 2004). The similar trend was observed by Estrada et al. (2004) in species richness of micro autotrophic plankton community along the salinity gradient in salterns.

Present study clearly suggested that salinity influences the planktonic population in the saltern ecosystem. The poor Artemia population may occur because of high salinity, temperature and low food (phytoplankton) in the water. Similar findings were observed by Kuruppu \& Ekaratne (1995). The fluctuation of Artemia population observed in the saltpans is being due to the seasonal influences (Davis, 1980).

In the present study survivability also showed an interesting fact that it persisted in the extreme halophilic environment of 117.33 ppt. According to Abatzopoulos et al. (2003) high salinities induce a reduction in the fertility of the females which caused declined in the population density during the summer season and the population density was maintained in station 2 by the supply of green water and reducing salinity. The input of freshwater during the monsoon season is the main reason for allows the water salinity to bring down for population development. During the water inflow the physicochemical parameter including salinity and temperature was optimized which triggered the hatching of cysts and increase reproductive rate of Artemia population. The brine 
shrimp Artemia showed a better growth performance and abundance in station 2. The maximum length of $9696.00 \mu \mathrm{m}$ was recorded in station 2 when compared with station 1 $(8729.44 \mu \mathrm{m})$. The amount of food particles in the diets could affect the energy availability for growth and survival to the Artemia.

Therefore the feeding of algae to brine shrimp is a prerequisite to support the aquaculture industry in order to improve nutritional quality, healthy growth and hatchery efficiency. Hence the study was concluded that among the four different seasons post-monsoon, pre-monsoon and monsoon seasons are suitable for the production of cysts and biomass from culture of brine shrimp and by supplying the green water.

\section{Acknowledgement}

All the author thankful to authorities of Bharathidasan University, Tiruchirappalli, India and Rajiv Gandhi Centre for Aquaculture, Tuticorin. India for provided the necessary facility to conduct this study.

\section{Conflict of interest}

Authors would hereby like to declare that there is no conflict of interests that could possibly arise.

\section{References}

Abatzopoulos TJ, El-Bermawi N, Vasdekis C, Baxevanis AD, Sorgeloos P (2003) Effects of salinity and temperature on reproductive and life span characteristics of clonal Artemia. International Study on Artemia, LXVI. Hydrobiologia 492: 191-199. DOI: 10.1023/A:1024826702830

Al Dhaheri S (2004) Assessment of Brine Shrimp (Artemia sp.) productivity at Al Wathba Wetland Reserve, Abu Dhabi, UAE. M.Sc. Thesis submitted to the University, Al Ain, UAE.

Amat FD (1979) Diferenciacion y distribucion de las poblaciones de Artemia (crustaceo branquiopodo) de Espana. Tesis Doctoral. Universidad Barcelona, Barcelona, Espana.

Asem A, Rastegar-Pouyani N (2008) Morphological differentiation of Artemia Günther 1899 (Crustacea: Anostraca) in different geographical stations from the Urmia Lake, Iran. Research Journal of Biological Sciences 3: 222228.

Ayadi H, Abid O, Elloumi J, bonain A, Sime Nagando (2004) Structure of the phytoplankton community in Avo lagoons of different salinity in the Sfax Salterns Tunisia. Journal of Plankton Research 26: 669-679.

Ben Naceur H, Ben Rejeb Jenhani A, Romdhane MS (2011) In situ study of adult Artemia salina morphometry and its relationships to the physicochemical water parameters in
Sahline saltwork (Tunisia). Oceanological and Hydrobiological Studies 40: 44-51. DOI: 10.2478/s13545-011-0040-5

Browne RA (1992) Population genetics and ecology of Artemia: Insights into parthenogenetic reproduction. Trends in Ecology \& Evolution 7: 232-237. DOI: 10.1016/01695347(92)90051-C

Browne RA (1993) Sex and the single brine shrimp. Natural History $102:$ p34

Camargo WN, Ely JS, Duran GC, Sorgeloos P (2004) Influence of some physicochemical parameters on Artemia biomass and cyst from the Colombian Caribbean. Journal of the World Aquaculture Society 35: 274-283. DOI:10.1111/j.1749-7345.2004.tb01085.x

Davis JS (1980) Importance of microorganism in solar salt production. In: Oagan AH (Ed) Proceeding of the Fourth symposium on Salt. Cleveland, PP. 369-372.

Davis JS (2000) Structure, function and management of the biological system for seasonal solar saltworks. Global Nest Journal $2: 217-226$

Dhont J, Lavens P (1996) Tank production and use of ongrown Artemia, P. 164-195. In: Lavens P, Sorgeloos P (Eds.) Manual on the production and use of live food for aquaculture. FAO Fisheries Technical Paper 361, Rome

Estrada M, Henriksen P, Gasol JM, Casamayor EO, PedrosAlio C (2004). Diversity of planktonic photoautotrophic microorganisms along a salinity gradient as depicted by microscopy, flow cytometry, pigment analysis and DNA based methods. FEMS Microbiology ecology 49: 281-293. DOI: 10.1016/j.femsec.2004.04.002

Geddes M, Williams WD (1987) Comments on Artemia introductions and the need for conservation. In: Sorgeloos P, Bengston DA, Decleir W, Jaspers E (Eds.) Artemia Research and its Applications, Universa Press, Wetteren, Belgium Pp, $19-26$.

Gelabert FR, y A. De la Cruz (1990) La selección del tamaño de partículas alimenticias por Artemia (Branchiopoda). Revista de Investigaciones Marinas11 : 63-69.

Gilchrist BM (1960) Growth and form of the brine shrimp Artemia salina (L.). Proceedings of the Zoological Society of London 134: 221-235.

Gunde-Cimerman N, Zalar P, De Hoog S, Plemenita A (2000) Hyper saline waters in salterns - natural ecological niches for hypophilic black yeasts. FEMS Microbiology Ecology 32 : 235-240. DOI: 10.1111/j.1574-6941.2000.tb00716.x.

Hontoria F, Amat F (1992) Morphological characterization of adult Artemia (Crustacea, Branchiopoda) from different 
geographical origin. Mediterranean populations. Journal of Plankton Research 14: 949-959. DOI: https://doi.org/10.1093/plankt/14.7.949.

Kulasekarapandian S, Ravichandran P (2003) Artemia cyst production at Kelambakkam near Chennai. Journal of Marine Biological Association India 45: 266 - 177.

Kuruppu MM, Ekaratne SUK (1995) Ecology and population structure of the Artemia Parthenogenetica population inhabiting a major salter in Srilanka. International Journal of salt Lake Research 4:117-131.

Lavens P, Sorgeloos P (1991) Production of Artemia in culture tanks. In: Browne RA, Sorgeloos P, Trotman CNA (Eds.) Artemia Biology, CRC Press, Boca Raton, FL, Ann Arbor Boston, pp: 317-351.

Lenz PH, Browne RA (1991) Ecology of Artemia. In Browne RA, Sorgeloos P, Trotman CNA (Eds) Artemia biology. Boca Raton: CRC Press, pp. 237-253.

Litvinenko LI, Kozlov AV, Kovalenko AI, Bauer DS (2007) Salinity of water as a factor to determine the development of the brine shrimp Artemia population in Siberian lakes. Hydrobiologia 576: 95-101. DOI: 10.1007/s10750-006-0296-8

Mason D (1963) The growth response of Artemia salina (L) to various feeding regimes. Crustaceana 5: 138-150. URL: http://www.jstor.org/stable/20141010

Persoone G, Sorgeloos P (1980) General aspects of the ecology and biogeography of Artemia.p.3-24. In: Persoone G, Sorgeloos P, Roels O, Jaspers E (Eds.).The brine shrimp Artemia.Vol. 3. Ecology, Culturing Use in Aquaculture. Universa Press, Wetteren,Belgium.456 p.

Radhika D, Veerabahu C, Nagarajan J (2011) Distribution of Phytoplankton and Artemia in the Solar Salterns at Tuticorin. Current World Environment 6: 233-239. http://www.cwejournal.org/?p=250

Razia Sultana, Faisal Ameer, Wajeeha Ali, Muhammed Nasir (2011) Culture of Vinhchau strain of Artemia franciscana
Kellogg, 1906 (Crustacea:Anostraca) in Pakistan. International Journal of Artemia Biology 1: 41-48.

Rehman AA (2006) Plankton communities in hyper saline waters of Indian solar salt work. Proceeding of the 1st International Conference on the ecological importance of solar salt work (CEISSA06), Greece, 20-22 October2006

Shaikha Al Dhaheri, Anitha Saji (2013). Water quality and brine shrimp (Artemia sp.) population in Al Wathba Lake, Al Wathba Wetland Reserve, Abu Dhabi Emirate, UAE. International Journal of Biodiversity and Conservation. 5 : 281-288

Sorgeloos P (1980) The use of the brine shrimp Artemia in aquaculture. In: Personne G, Sorgeloos P, Roels O, Jaspers E (Eds) The brine shrimp Artemia. Volume 3. Ecology, culturing, use in aquaculture. Wetteren: Universa Press, pp. $27-46$.

Sorgeloos P, Lavens P, Léger P, Tackaert W, Versichele D (1986) Manual for the culture and use of brine shrimp Artemia in aquaculture. The Belgian Administration for Development Cooperation. The Food and Agriculture Organization of the United Nations. Artemia Reference Centre, State University of Ghent, Belgium-Faculty of Agriculture.

Tackaert W, Sorgeloos P (1991) Semi-intensive culturing in fertilized ponds: 287-315. In: Browne RA, Sorgeloos P, Trotman CAN (Eds), Artemia Biology. CRC Press, Inc., Boca Raton, Florida, USA, 374 p.

Van Stappen G (2002) Zoogeography. In: Abatzopoulos TJ, Beardmore JA, Clegg JS, Sorgeloos P (Eds.) Artemia: basic and applied biology. Dordrecht: Kluwer Academic Publishers, pp. 171-215.

Vanhaecke P, Sorgeloos P (1980) International Study on Artemia. IV. The biometrics of Artemia strains from different geographical origin. In: Persoone G., Sorgeloos P, Roels O, Jaspers E (Eds.) The brine shrimp Artemia 3. Universa Press, Wetteren (Belgium): 393-405. 